\title{
Factors that Affect Job Satisfaction of Academic Employee
}

\author{
Karina Putri Alamanda ${ }^{1 *}$, Desita Dyah Damayanti ${ }^{1}$, Dewi Kamaratih ${ }^{1}$,
} Aniq Hudiyah Bil Haq ${ }^{1}$

\author{
${ }^{1}$ Department of Economic, Law, Politic, and Psychology, Universitas Muhammadiyah Kalimantan Timur, Samarinda, \\ Indonesia \\ *Corresponding author. Email: kpa520@umkt.ac.id
}

\begin{abstract}
Employee satisfaction was a major issue affected organizational goals through the performance and achievements of its employees. Job satisfaction also affects employee's life satisfaction and vice versa. The purpose of this research was to find out the factors that influence job satisfaction and the design a program to increase job satisfaction. The data was collected by an interview and observation through purposive sampling selection techniques to 7 employees with high, medium and low levels of job satisfaction. The results indicate that work-it-self, leadership, coworkers, advancement, salary, working conditions, customer satisfaction and individual value was the factors that influence job satisfaction. Further, forms of job satisfaction were applied in four forms behavioral (exit, neglect, voice, and loyalty). Then, the program which can be applied was interpersonal communication skills training. Interpersonal communication skills were intended to support work changes that occur and improve relations between leaders and employees. The programs provide persuasion, openness and empathy in communication skills. By paying attention to employee satisfaction and managing it, had an impact on organizational objectives and related to psychological well-being of employees.
\end{abstract}

Keywords: qualitative research, job satisfaction, academic employee, university

\section{INTRODUCTION}

Human resources are the main power in organizational movement and organizational achievement [1] because they give talent, expertise, knowledge and experience to achieve organizational goals [2]. Employee sustainability to produce performance as expected by the organization becomes important. Thus, the organization needs to analyze job satisfaction as an evaluation for organizational achievement.

Job satisfaction defined as a pleasant feeling as a result of employee perceptions of achieving or providing opportunities to achieve work values which is considered important by employees [3]. In line with that, job satisfaction defined as a series of pleasant and unpleasant feelings and emotions according to the employee's view of his work [4]. Feeling satisfied or dissatisfied with his work was something personal, depends on how he perceives the suitability or conflict between his desires with the results obtained, include values that are perceived important by employees, that is goals to be achieved in work.

Data by interview as a preliminary study, found that, academic office at unit $\mathrm{X}$, informed that the performance of its employees was considered disappointing, related to discipline, work competence, work commitment and even to refuse the job. The results of the customer satisfaction survey (students), stated the same thing. Employees are less enthusiastic, less disciplined, incompetent and do not understand their work assignments, thus the services are slow, long-winded, less responsive, unfriendly and unempathy towards students' needs.

Job satisfaction is influenced by seven aspects, such as jobs itself, working conditions, rewards (salary or incentives), policies and procedures, co-workers and promotion opportunities [5]. Theory of value perception states that values considered important by employees also determine satisfaction and dissatisfaction with work. If the expected values are not fulfilled, it will make employees feel dissatisfied. While job satisfaction proven affect work motivation and further to employee performance [6]. Motivation has a significant impact on job satisfaction [7]. Work dissatisfaction does not only have an impact on employee performance and affect the achievement of overall organizational goals, but also affects someone's satisfaction in living his life [6] [8]. Unbeneficial condition, because despite of disrupting mental health actually if an employee has a good satisfaction of life (happy non-work life), then it also affects the experience and meaning in work. In other words, job satisfaction and life satisfaction, both influence each other [6], so do with work family conflict and social support that effect on job satisfaction [9]. Considering the importance and typical characterization of job satisfaction among employees was the main purpose of this study, carried out on the factors that affecting job satisfaction of academical employees, especially in unit X. 


\section{RESEARCH METHOD}

This qualitative research had meaning to understand the phenomena about what is experienced by the research subject holistically and poured in a descriptive manner (words and language) in a special natural context by utilizing various methods [10]. This method used to help researchers to answer research questions in describing the factors that affect employee job satisfaction.

The participants using purposive sampling, which use the MSQ scale (Minnesota Satisfaction Questioner) compiled by Weiss, Dawis, England, \& Lofquist [11] as preliminary data to 20 employees of unit X. Further, 7 employees were selected that describe the three level of jobs satisfaction, high, average and low, to do interviews as qualitative data. Data analysis was carried out by organizing data, (1) recording the results of interviews in full (verbatim results),

(2) classifying themes through the results of the matrix and (3) presenting the results of the analysis.

\section{RESULTS AND DISCUSSION}

\subsection{Result}

Table 1 The Supporting Data from The Participants

\begin{tabular}{|c|c|c|c|c|}
\hline & Subject 1 & Subject 2 & Subject 3 & Subject 4 \\
\hline Sex & $\mathrm{M}$ & $\mathrm{M}$ & $\mathrm{M}$ & $\mathrm{F}$ \\
\hline Age (year) & 56 & 43 & 53 & 28 \\
\hline Education & $\begin{array}{c}\text { Senior } \\
\text { High }\end{array}$ & $\begin{array}{l}\text { Senior } \\
\text { High }\end{array}$ & $\begin{array}{l}\text { Senior } \\
\text { High }\end{array}$ & Bachelor \\
\hline Position & $\begin{array}{c}\text { Head of } \\
\text { affairs }\end{array}$ & Staff & $\begin{array}{c}\text { Head of } \\
\text { affairs }\end{array}$ & Staff \\
\hline $\begin{array}{l}\text { Work } \\
\text { experience } \\
\text { on } \\
\text { university }\end{array}$ & 39 year & 21 year & 31 year & 4 year \\
\hline $\begin{array}{l}\text { Work } \\
\text { experience } \\
\text { on unit }\end{array}$ & 8 year & 3 year & 31 year & 4 year \\
\hline \multirow[t]{2}{*}{$\begin{array}{l}\text { MSQ's } \\
\text { category }\end{array}$} & Low & Average & High & High \\
\hline & \multicolumn{2}{|c|}{ Subject 5} & ect 6 & Subject 7 \\
\hline Sex & \multicolumn{2}{|c|}{$\mathrm{F}$} & & $\mathrm{M}$ \\
\hline Age (years old) & \multicolumn{2}{|c|}{52} & & 52 \\
\hline Education & \multicolumn{2}{|c|}{ Diploma } & elor & Senior High \\
\hline Position & \multicolumn{2}{|c|}{ Staff } & $\begin{array}{l}\text { d of } \\
\text { ion }\end{array}$ & Staff \\
\hline $\begin{array}{l}\text { Work experience } \\
\text { on university }\end{array}$ & \multicolumn{2}{|c|}{27 year } & 29 year & 26 year \\
\hline $\begin{array}{l}\text { Work experience } \\
\text { on unit }\end{array}$ & \multicolumn{2}{|c|}{10 year } & 12 year & 12 year \\
\hline MSQ's category & \multicolumn{2}{|c|}{ Average } & & Average \\
\hline
\end{tabular}

The participants consisted of different sex, ages, education level, and work experience. It was expected to provide a comprehensive picture of the employees' job satisfaction of Unit X.

Factors that affect job satisfaction of Unit X employees was six factors there are:

\subsubsection{Work it self}

The participants generally convey work factors affecting job satisfaction, the clarity of task and given full responsibility in completing the work, the task in accordance with the field being mastered, and when the task can be completed on time. Completion of tasks is considered to be the main thing for employees, even though the workload was high but according to expertise and can be completed on time, there was fine.

However, the information regarding the division of tasks in terms of both quantity and quality which are considered by employees to be inappropriate. Changes the services system and employees' reductions (transfers and retirement) provide a consequence of increased work duties even for certain who do not have a coordinator, so it is unclear who the task is assigned to. The amount and burden of work given to employees which affects the difference earned. Reduction of employees due to retirement also impacts the suitability of the division, capacity or ability of employees, levels of education and positions held. Employees assess that between staff and head of affairs staff, had the same burden and responsibility. Thus, the employee feels that his work assignments are less challenging and assesses the leader is less skilled in distributing work to his employees. Based on these data it can be concluded that work itself factors affect job satisfaction of all employees. Work related matters such as managing tasks, speed, work continuity, work error rate, work challenges and rule system, affect employee job satisfaction.

\subsubsection{Leader}

The role of leaders as implementing policies [12] and role models for employees, in general, was considered to have an influence on employee satisfaction at work. The figure of the leader that affects the work satisfaction of employees when the leader is satisfied with the work of employees, has an Islamic value and applied on that, build a comfortable and humorous work atmosphere, team work, and consider the advice of his subordinates. The role of leadership inseparable from work itself, such as employee management, decision making, determination of benefits, and the understanding of duties of employees.

Another thing related to leadership was attitude, which includes ways of communication, emotional control, social relations leaders-employees, as well as opportunities to express opinions both verbal and text. Leaders responses on emotional state makes employees reluctant to express opinions. The age of the leader considered to effect on emotional management of his emotional appearance. Furthermore, employees expect the leader to be more active in building relationships with employees.

Employees who judge that the leadership influences their satisfaction at work, tend to be satisfied with the role of the leader. As for employees who are dissatisfied with the role of the leader said that the leader has no influence on job satisfaction or on the appearance of work. It can be concluded that the role of the leader is inseparable from employee job satisfaction, but his appreciation is very dependent on each employee's personal meaning in the 
leadership role. However, the leadership is expected to continue to have a role in creating a professional and comfortable work atmosphere.

\subsubsection{Co-worker}

The cooperation, reminding and helping each other, except for certain jobs, makes co-workers influence employee job satisfaction. This applies to new employees, but not to the leaders. Feeling uncomfortable to giving work direction makes employees feel reticent to the leadership. In addition, there are two things that employees complain about, first, work responsibilities and honorarium. At certain times, coworkers were not at office so it is considered to lack of responsibility. The difference in salaries earned often causing conditions that intersect between employees. This makes some employees reluctant to be involved in work with the addition of salaries which actually has an impact on dissatisfaction with the relationships to the co-workers. But it does not affect the communication and appearance of employee work.

Thus, it can be seen that job satisfaction is inseparable from the factors of co-workers. Co-workers are not only interpreted as relations between employees but relation between inter-relationship and work performance. The continuity of work, distribution $\mathrm{n}$ of work that effect on additional earned, and the relations of co-workers also influence the relationship between co-workers. The role conflict and role ambiguity effect on job satisfaction [13].

\subsubsection{Promotion}

Promotion system that is not fully understood by employees and unclear rules affect employee dissatisfaction. Furthermore, it has an impact on the employee's assessment of the leadership, especially those who get promotion opportunities but do not master their work. Another impact related to dissatisfaction and distrust of the promotion system was the reluctance of employees to be promoted. Beside the distrust of the system, employees avoid misunderstanding with peers and worry about not being able to carry out the responsibilities. As a concluded, the promotion factor was considered by employees to have no influence on job satisfaction or job performance. This is because employees are generally not satisfied with the promotion system in force.

\subsubsection{Salary}

The assessment of salary earned is interpreted differently Employees who assess salary are quite appropriate, believe that the amount was sufficient to support their family and salary is not the main purpose of work. In addition, a positive view of the company, that if the agency has more ability, then there will be an increase in salary and when compared with other companies was better. Whereas, employees who judge not suitable, assume that the amount is not in accordance with the workload. In addition, there are salary deductions that are considered inappropriate and without any agreement. Overall the most important thing for employees is job responsibilities. No matter how much nominal was received, it is still grateful even if it is felt to be inappropriate and it has no effect on the work appearance of employees.

\subsubsection{Work condition}

Employee responses about working conditions are divided into two things, that is services settings and infrastructure. According to the employees, the arrangement of workspace for student services was inappropriate, less conducive and less comfortable, both for students and for employees. Working conditions are generally considered by employees to affect the completion of work. Due to the availability of facilities and infrastructures that help the work of employees. It does not directly affect employee job satisfaction because work completion is the main thing compared to work space conditions.

\subsubsection{Customer satisfaction}

Another factor that affects employee job satisfaction was customer (student) satisfaction with the services provided. Employees feel satisfied when the services satisfy students. In addition, employees seem to pay attention to customer satisfaction at work and make it as another form of reward beside to material value.

\subsubsection{Years of service}

Years of working in certain organizations give employees the opportunity to see the development of company and work units. Where it also provides job satisfaction for employees. Not limited to being able to witness the development of company and units, but also being part of and giving contribution to the development of the organization.

\subsubsection{Values}

Other factors that influence employee job satisfaction are the values that are believed by employees, such as freedom to worship, working hours, individual self-assessment and control, agency policies, leadership, work, and family relations within the company.

In theory, some figures say that the factors that influence job satisfaction are work, salary, leadership, co-workers, personality, working conditions, promotion and ethnic culture [14] [15] [16] [17] [18] [3].

\subsection{Discussion}

Based on the data, it is known that each employee has a different meaning related to factors that affect job 
satisfaction. This difference depends on the tendency of each personality in dealing with situations that make him enjoy his work [17]. There are people who are generally satisfied, motivated, and enthusiastic without considering the type of work. But there are also people who basically always complain whatever the job. In this discussion the factors that influence job satisfaction of Unit X employees are work, leadership, co-workers, promotions, salaries, working conditions, customer satisfaction, years of service and values believed by individuals. Some previous theories and research convey the same thing, although it does not thoroughly mention these factors. Some of them which are often conveyed affect job satisfaction are work factors, leadership, co-workers, promotions, salary, and working conditions [14] [15] [16] [19] [20] [3] [21].

Intrinsic characteristics of work (diversity, difficulty, amount of work, responsibility, autonomy, control of work methods, and creativity) or inferred mental challenges in working determine job satisfaction [14] [16] [18] [3] and contribute to work motivation [15]. Another thing to note was the role imbalance and ambiguity, as well as work role imbalances which also influence job satisfaction [19]. Thus, the job factor clearly affects employee job satisfaction.

Related to leadership factors, professional work relations reflect the extent to which superiors assist employees in satisfying work values that are important to him, namely by providing opportunities to participate and influence (change) for company [15]. It is further known that transactional leadership type is a major factor related to job satisfaction [22]. Transactional leadership is indicated by the closeness between leaders and employees, that is, leaders can accommodate between organizational goals and individual goals (employees); can convince employees that they can provide good work results; and can motivate employees to achieve the goals and objectives of the agency as a whole. When the leader can motivate employees to work and strive to achieve organizational goals and employee goals simultaneously, it can affect job satisfaction of employees [22]. Including the choice of communication styles (supportive and autocrative) also have a relationship with job satisfaction [19].

The role of superiors and co-workers in job satisfaction is explained through two things, first, the similarity of values, attitudes, and philosophies or views between the two and the relationships that provide mutual support for sympathy and concern. The second point, if the relationship is built to support each other, it will help to achieve their respective goals (social support). Based on research, social support is the main predictor of job satisfaction and decreases employee turnover [3]. Thus, in building relationships between leaders and employees need to foster social relations and provide moral support to one another. Then related to co-workers, fluency in the implementation of work, distribution of tasks and relationships among coworker also influence job satisfaction [16], which can be invited to work together and provide assistance when needed [21].

Factors of work conditions and promotions that are interpreted negatively by employees contain the notion of dissatisfaction in both aspects. However, a positive work environment and provide opportunities to develop intellectual capacity and basic skills are more important than promotion opportunities [15]. In addition, if the results, treatment and procedures of the organization are carried out fairly, job satisfaction will be created which in turn affects Organizational Citizen Behavior (OCB). Thus, trust in the company will develop, so employees will be willing to engage voluntarily [12]. In other words, job satisfaction has a significant relationship to OCB [17] [24] [16].

Salary is a symbol of achievement, success, recognition, and company appreciation for employee contributions. However, the salary received is felt to be fair is an important thing. The salary is perceived as fair based on job demands, individual skill levels, and salary standards that apply to certain occupational groups, job satisfaction will be created [14] [15] [16] [18] [3]. In addition, the amount of salary received by an individual when compared to the same job in different places, becomes more important for employees than the level of salary applied in the company where he works [3]. Thereby maintaining employee perceptions about fairness and making overall adjustments become a periodic agenda that needs to be considered.

Consumer satisfaction also affects employee job satisfaction [24] [20] and can be a major factor in employee job satisfaction [20], because it will affect the appearance in providing services to consumers and the services provided will further affect customer satisfaction [25]. When services are provided directly or face to face, the relationship between job satisfaction and customer satisfaction is higher than indirect services. This is because consumers can directly observe attitudes, processes, and receive services and can interact directly [26].

Values that are believed by employees was one of the factors that are felt by employees affect job satisfaction. The values of the work that are considered important but not fulfilled will make employees feel dissatisfied [6]. Thus job satisfaction for each employee is interpreted differently according to the values he believes. These various values are very individual such as the principle of protecting the environment or healthy living, the closeness of social relations, and some of them [26].

Based on the analysis, it is known that job satisfaction of employees on Unit X was influenced by factors of work, leadership, co-workers, promotion systems, salaries, working conditions, customer satisfaction and individual values. In addition, it was found that building openness in communication between leaders and employees became the focus of resolution on this unit. Therefore, the planned program recommendation is interpersonal communication [26]

Openness in the communication process requires the desire of each individual to try to understand other people's perspectives, thoughts and feelings of others or in other words empathize with others. Individuals who can empathize with the conditions of others will be able to understand the experiences, feelings, attitudes, hopes and desires of others so that the communicator (himself or the interlocutor) is better able to adjust their communication patterns [27]. The interpersonal communication approach can be used to build teams [28], that is changing the climate and group processes through open opportunities in conveying how each group member feels and how they interact. As for the group climate he meant among others was to increase trust, cooperation and group cohesiveness. 
Management. Internastional Journal of Supply Chain Management, Vol. 7, No. 2, 2018.

[8] E. A. Cooper, C. L., \& Locke, Industrial and Organizational Psychology: Linking Theory with Practice. Malden: Blackwell Business., 2000.

[9] R Zirwatul Aida R Ibrahim, Jumadil Saputra, Azlina Abu Bakar, Mazidah Mohd Dagang, Siti Nazilah Mat Ali, Md Aris Safree Md Yasin. Role of Supply Chain Management on the Job Control and Social Support for Relationship between Work-Family Conflict and Job Satisfaction. Internastional Journal of Supply Chain Management, Vol. 8, No. 4, 2019.

[10] L. J. Moleong, Metodologi Penelirian Kualitatif., PT. Remaja. Bandung, 2005.

[11] L. H. Weiss, D. J., Dawis, R. V., England, G. W., \& Lofquist, Minnesota Studies in Vocational Rehabilitation: xxii Manual for the Minnesota Satisfaction Questionnaire. Minneapolis dan Saint Paul, Minnesota: Work Adjustment Project Industrial Relations Center University of Minnesota., 2019.

[12] Nizam Sarkawi, Abdul Rahman Jaafar, Jauriyah Shamsuddin, Noor Fareen Abdul Rahim, Efrizal Syofyan. Influence of Growth Need Strength on the Relationship between Overall Life Satisfaction and Job Satisfaction for Medical Service Quality and Delivery. Internastional Journal of Supply Chain Management, Vol. 8, No. 4, 2019.

Jakarta: Erlangga, 2012.

[2] J. Gaol, C., \& L, A to Z Human Capital (Manajemen Sumber Daya Manusia) Konsep, Teori dan Pengembangan dalam Konteks Organisasi Publik dan Bisnis. Jakarta: PT. Gramedia Widiasarana, 2014.

[3] A. Kreitner, R., \& Kinicki, Perilaku Organisasi (9 ed.). Jak: Salemba Empat, 2014.

[4] J. W. Newstrom, Organizational Behavior: Human Behavior at Work (13 ed.). New York: McGraw-Hill International Edition.

[5] R. E. Riggio, Introduction to Industrial/Organizational Psychology (6th ed.). New Jersey: Pearson Education, 2013.

[6] M. Afifah, T., \& Al Musadieq, "Pengaruh Kepuasan Kerja Terhadap Motivasi Kerja dan Dampaknya Terhadap Kinerja (Studi Pada Karaywan PT. Pertamina Geothermal energy Kantor Pusat Jakarta).," J. Adm. Bisnis, pp. 122-129.

[7] S. Poongavanam. A Study On Motivation And Job Satisfaction With Referent To Ware House
[13] Wirson Bongga, Ade Irma Susanty. he Influence of Role Conflict and Role Ambiguity on Employee Job Satisfaction of Transportation Companies in Indonesia. Internastional Journal of Supply Chain Management, Vol. 7, No. 2, 2018.

[14] A. S. Munandar, Psikologi Industri dan Organisasi. Jakarta: UI-Press, 2001.

[15] F. Luthans, Organizational Behavior (9 ed.)., vol. 75. Ne: Mc-Graw Hill Irwin.

[16] T. A. Robbins, S. P., \& Judge, Perilaku Organisasi (12 ed.). Jakarta: Salemba Empat, 2007.

[17] M. G. Aamodt, Industrial/Organizational Psychology: An Applied Approach (5 ed.). Belmont: Thomson Wadsworth, 2019.

[18] P. E. Spector, Industrial and Organizational Psychology (5 ed.). Hokoben: John Wiley \& Sons., 2008.

[19] S. P. Ruel, Factors Influencing Nurse Faculty's job Satisfaction and Intent to Stay. Mississippi: Graduate 
[24] A. Al-Hinai, Z., \& Bajrachary, “A Study on the Factors Affecting Job Satisfaction of Academic Staff in Higher Education Institution.," in 13th International Academic Conference, 2014, pp. 13-24.

Job Satisfaction Among Radiation Therapy Faculty.," J. Allied Health, no. 38, pp. 163-169, 2009.

[21] I. Saba, "Measuring the Job Satisfaction Level of the Academic Staff in Bahawalpur Colleges,"

Tnternational J. Acad. Bus. Soc. Sci. 1.

[22] H. Baltaci, F., Kara, E., Tascan, E., \& Avsalli, "The Effect of Leadership On Job Satisfaction (Visionary Leadership, Transformational Leadership, Transactional Leadership),” J. Hum. Resour. Sustain. Stud., vol. 9, pp. 211-227, 2012.

[23] W. Guo, T. Li, and N. Wu, "Empirical Study on the Effects of Leader' s Verbal Communication Style on Employee' s Job Satisfaction," no. December, pp. 211-227, 2015.
[25] Z. Z. Kermani, "A Study of the Linking Between Job Satisfaction and Customer Satisfaction: A Case Study of Iran insurance, Kerman, Iran.," J. Mark. Dev. Compet., pp. 104-109, 2013.

[26] C. O. Mendoza, M. L., \& Maldonado, "MetaAnalysis of the Relationship between Employee Satisfaction and Customer Satisfaction.," pp. 4-9, 2014.

[27] N. Adler, R. B., Proctor, R. F., \& Towne, Looking Out, Looking In (11th ed). be: Thomson Wadsworth, 2005.

[28] L. Millward, Understanding Occupational \& Organizational Psychology. London: Sage Publications, 2005. 